\title{
Hamartoma: Diagnostic Procedure of Unspecific Clinical Appearance in the Oral Cavity
}

\author{
Ahmad Ronal, Febrina Rahmayanti \\ Department of Oral Medicine, Faculty of Dentistry, Universitas Indonesia \\ Correspondence to: Email: ahmadronal@gmail.com
}

\begin{abstract}
Hamartoma is a benign tumor-like lesion composed of overgrowth of mature cells and tissues. Along with its unspecific appearance, it may occur in the oral cavity and bear resemblance to the other lesions. In this report we describes the clinical appearance of hamartoma as well as the diagnosis method in the case of a 37-year-old-man. The patient explained that he already has redness plaque lesion on his skin left cheek region since he was born. The lesion was sensed to grow and discomfort at the age of 22. A surgical therapy had been performed to reduce the size of lesion one year after, but the redness plaque still existed. Thirteen years following the operation, white lesion appeared on the inner left cheek $10 \times 8.5 \times 6$ $\mathrm{cm}$ of size and extended onto lower lips within half a year. Diagnostic procedure was carried out such as biopsy, CT-scan and radiography with neuroma as an initial conclusion. New histopathological examination confirmed the diagnosis of hamartoma. It is concluded that adequate and appropriate biopsy procedure along with sufficient clinical information are needed to develop a proper diagnosis to distinguish hamartoma from other oral lesions.
\end{abstract}

\begin{abstract}
Abstrak
Hamartoma: Prosedur diagnosis pada kasus dengan tampilan klinis yang tidak spesifik. Hamartoma merupakan lesi dengan disorganisasi pertumbuhan sel matur dan jaringan yang berlebihan, dapat terjadi di rongga mulut dengan gambaran tidak khas dan menyerupai neoplasma. Laporan kasus ini memaparkan gambaran klinis hamartoma beserta penegakan diagnosisnya pada pasien pria 37 tahun. Pasien tersebut memiliki riwayat lesi kulit berupa plak merah pada pipi kiri yang telah terlihat sejak lahir. Lesi tersebut dirasakan membesar dan mengganggu pada usia 22 tahun. Setahun kemudian dilakukan operasi pengurangan massa lesi, namun tetap meninggalkan gambaran kemerahan. Tiga belas tahun setelah operasi, timbul lesi putih di pipi kiri bagian dalam yang dalam waktu setengah tahun membesar hingga berukuran 10 × 8,5 x $6 \mathrm{~cm}$ dan meluas sampai bibir bawah. Prosedur diagnosis dilakukan berupa pemeriksaan klinis dan penunjang yakni biopsi, CT scan, dan radiograf dengan kesimpulan awal neuroma. Selanjutnya dilakukan biopsi ulang dengan kesimpulan diagnosis hamartoma. Disimpulkan bahwa biopsi yang adekuat dan representatif, serta penyertaan informasi klinis yang memadai diperlukan untuk membedakan hamartoma dengan lesi oral lainya.
\end{abstract}

Keywords: hamartoma, diagnostic procedure

\section{PENDAHULUAN}

Dalam istilah klinis, tumor sering digunakan untuk semua tonjolan dan diartikan sebagai pembengkakan, meskipun dalam ilmu patologi anatomi istilah tumor identik dengan neoplasma. Pembengkakan dapat disebabkan baik oleh proliferasi seluler, maupun oleh peradangan, perdarahan, dan sebagainya. ${ }^{1}$ Proliferasi seluler dapat dikelompokkan menjadi hiperplasia, hamartoma, choristoma, teratoma, neoplasma jinak, dan neoplasma ganas. ${ }^{2}$ Istilah hamartoma (hamartia : cacat) pertama kali diperkenalkan oleh Albrecht (1904) untuk menandakan malformasi nonneoplastik menyerupai tumor atau kegagalan bawaan lahir pada perkembangan satu dari tiga lapisan embrional (ektoderm, mesoderm, dan endoderm). Malformasi tersebut menghasilkan jumlah sel yang berlebihanyang akan mencapai dewasa dan 
berhenti bereproduksi, sehingga pertumbuhannya terhenti dengan sendirinya. Hal ini dapat terjadi saat kelahiran atau merupakan bawaan yang menunjukkan pertumbuhan hingga masa remaja. Istilah hamartoma hanya digunakan bila ditemukan adanya anomali perkembangan. Hamartoma umumnya muncul dari kulit atau jaringan subkutan, ginjal, paru, hati, limpa, dan traktus gastrointestinal. ${ }^{3}$

Pada makalah ini akan diulas suatu kasus hamartoma pada seorang laki-laki 37 tahun, dengan lesi intraoral. Penulisan laporan ini bertujuan untuk memaparkan gambaran klinis hamartoma dan proses penegakan diagnosisnya sehingga dapat menjadi salah satu kepustakaan dalam proses penegakan diagnosis pada kasus dengan proliferasi selular di regio oral.

\section{LAPORAN KASUS}

Pasien pria, usia 37 tahun datang ke Poli Penyakit Mulut, Departemen Gigi dan Mulut RS Dr.Cipto Mangunkusumo (RSCM) berdasarkan konsul dari Poli Telinga Hidung dan Tenggorokan (THT) dengan diagnosa kerja curiga kanker pipi dengan permohonan evaluasi dan tatalaksana di bidang gigi dan mulut. Penatalaksanaan yang telah dilakukan di Poli THT ialah biopsi yang diambil dari lesi regio bukal pada area yang paling keras. Sampel biopsi merupakan empat keping jaringan, bentuk lonjong, ukuran 4 × 3 × $2 \mathrm{~mm}$ sampai $8 \times 4 \times 3 \mathrm{~mm}$, coklat, dan kenyal. Selain itu pasien juga dikonsulkan untuk melakukan pemeriksaan laboratorium hematologi, radiografi toraks, dan CT (computed tomography) scan maksila.

Pasien menyatakan riwayat adanya flek merah di pipi kiri sejak lahir dan mulai membesar saat berusia 22 tahun. Satu tahun setelah flek tersebut mulai membesar, dilakukan operasi untuk menghilangkan pembesaran tersebut, namun kemerahan tidak hilang. Tiga belas tahun setelah operasi, timbul sariawan kecil di pipi kiri bagian dalam, berwarna putih dan kemudian membesar sehingga pasien berobat ke RSCM setahun kemudian. Pasien tidak memiliki riwayat mengkonsumsi alkohol. Mie instan atau makanan cepat saji lainnya, penyedap makanan, serta ikan asin, jarang dikonsumsi. Bapak pasien merokok beberapa batang per hari. Tidak ada riwayat kontak dengan bahan kimia. Keluhan rongga mulut yang dirasakan pasien ialah hanya dapat mengunyah pada sisi kanan, karena adanya tumor di sebelah kiri. Dua minggu yang lalu, tambalan gigi sebelah kanan lepas sehingga gigi terasa sakit, dan sulit mengunyah. Pada sekitar permukaan massa yang membesar di bagian dalam pipi sering terjadi perdarahan namun tanpa disertai nyeri. Sedangkan pada bagian luar, terasa baal. Sikat gigi tetap dilakukan dua kali per hari (pagi dan sore). Pasien tidak menggunakan obat kumur. Berdasarkan anamnesa tidak ditemukan adanya riwayat penyakit sistemik.

Pada pemeriksaan klinis, terlihat massa di sisi bukal kiri meluas hingga bibir bawah, konsistensinya kenyal cenderung keras dengan bagian dalam pipi lebih keras. Massa tersebut tidak berlobus, sedikit hangat, berukuran $10 \times 8,5 \times 6 \mathrm{~cm}$, padat, terfiksasi, nyeri tekan negatif, permukaan intraoral verukosa, dan terdapat eritema dengan dasar putih kekuningan (Gambar 1). Pada pemeriksaan intraoral terlihat kebersihan rongga mulut yang sedang dengan kalkulus subgingiva dan supragingiva. Seluruh dorsum lidah mengalami coating tipis keputihan. Sedangkan pemeriksaan gigi geligi memperlihatkan sisa akar di 2.4, karies mencapai pulpa di 3.8, dan karies dentin di 4.7. Berdasarkan pemeriksaan yang dilakukan, pasien didiagnosis curiga tumor jaringan lunak, gingivitis marginalis kronis, 2.4 gangren radiks, 3.8 nekrosis pulpa, dan 4.7 hiperemia pulpa.

Kepada pasien diinstruksikan untuk tetap menyikat gigi dua kali per hari pada pagi hari setelah sarapan dan malam sebelum tidur, serta menyeka lesi dengan kasa yang dibasahi 
dengan air garam hangat. Tindakan dental yang akan dilakukan ialah penumpatan 4.7. Namun, pembersihan karang gigi serta tindakan pada 2.4 dan 3.8 ditunda sampai ada hasil pemeriksaan histopatologi yang dirujuk dari bagian THT. Dua minggu setelahnya, pasien datang kembali membawa hasil pemeriksaan histopatologi dari Departemen Patologi Anatomi (PA) atas biopsi yang dilakukan di Poli THT. Pemeriksaan mikroskopis memperlihatkan jaringan yang tampak membentuk massa multinoduler kecil hingga besar, yang terdiri dari sel-sel berbentuk kumparan dengan inti yang berlekuk, dibatasi oleh jaringan ikat internoduler dan tampak pula perdarahan yang luas dengan area-area nekrotik disekitarnya, disertai sebukan ringan sel radang kronik dan sel PMN (polymorphonuclear neutrophil) (Gambar 2). Sehingga disimpulkan lesi merupakan tumor jinak neuroma disertai dengan perdarahan.

Selain pemeriksaan histopatologi, pemeriksaan penunjang lainnya yang telah dilakukan ialah pemeriksaan laboratorium hematologi, radiografi toraks, dan CT scan maksila. Pemeriksaan hematologi yang meliputi pemeriksaan darah perifer lengkap, hemostasis, dan kimia klinik menunjukkan nilai yang relatif dalam rentang normal. Pemeriksaan radiografi toraks dengan proyeksi PA (posterior anterior) memperlihatkan tidak tampak kelainan radiologis pada jantung dan paru, serta tidak tampak tanda-tanda metastasis. Sedangkan pemeriksaan CT scan maksila menyimpulkan adanya massa jaringan lunak labia superior meluas ke daerah bukal kiri dengan erosi tulang mandibula kiri disertai limfadenopati submandibula kiri. Berdasarkan hasil pemeriksaan yang didapatkan, maka dilakukan tindakan dental di Departemen Gigi dan Mulut berupa pembersihan karang gigi, penambalan 4.7, dan pencabutan 2.4. Adapun pencabutan pada 3.8 tidak dilakukan oleh Poli Bedah Mulut karena terbatasnya lapang pandang dan menghindari resiko pencabutan yang berlebihan disebabkan letak gigi yang berada di regio tepi lateral pembesaran massa.

Setelah melalui rangkaian perawatan dental, pasien kembali ke Poli THT untuk melakukan perawatan definitif. Berdasarkan informasi yang didapat dari hasil pemeriksaan histopatologi yang didukung oleh pemeriksaan laboratorium hematologi, radiografi toraks, dan $\mathrm{CT}$ scan maksila, maka disimpulkan bahwa pembesaran massa tersebut merupakan neuroma bukal. Persiapan operasi dilakukan dengan melibatkan divisi THT Onkologi dan divisi Plastik Rekontruksi THT. Operasi didahului oleh pemeriksaan potong beku dari Departemen PA, dengan hasil pemeriksaan memperlihatkan ditemukannya proliferasi kapiler dan sel fibroblast. Jaringan serabut saraf menebal dengan diameter bervariasi (fleksiformis). Terlihat jaringan lemak matur dan jaras-jaras otot. Sehingga disimpulkan gambaran mikroskopik memberikan gambaran yang tidak bertentangan dengan jaringan granulasi dan neuroma. Untuk kepastian diagnosis disarankan untuk menunggu sediaan blok parafin.

Setelah pemeriksaan potong beku, direncanakan wide excision untuk mengangkat massa tumor yang dilanjutkan dengan labioplasti, namun terkendala perdarahan yang sangat banyak. Operasi dihentikan dan dilakukan pengambilan sampel jaringan berukuran $0,5 \times 0,5 \times 0,3 \mathrm{~cm}$, kecoklatan, kenyal pada jaringan sebelah dalam regio bukal untuk pemeriksaan histopatologi. Pada sisa potong beku, juga dilakukan pemeriksaan histopatologi terhadap sampel ukuran 1 x $0,5 \times 0,3 \mathrm{~cm}$ dan $0,5 \times 0,5$ $\mathrm{x} 0,2 \mathrm{~cm}$, kecoklatan, kenyal. Gambaran mikroskopik menunjukkan jaringan saraf yang menebal dengan ukuran bervariasi, setempat tampak tersusun palisading, yang terdapat di antara jaringan ikat. Tampak pula jaringan lemak matur dan jaringan otot lurik. Tampak pula sebukan ringan sel radang menahun. Pembuluh darah proliferatif dengan 
dinding sklerotik (Gambar 3). Sehingga dari hasil pemeriksaan ini disimpulkan gambaran lebih sesuai dengan hamartoma.
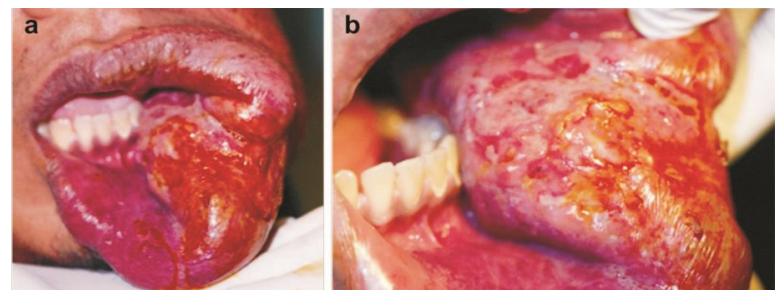

Gambar 1. Massa meluas dari sisi bukal kiri hingga bibir bawah, (a) permukaan intraoral verukosa, (b) terdapat eritema dengan dasar putih kekuningan.

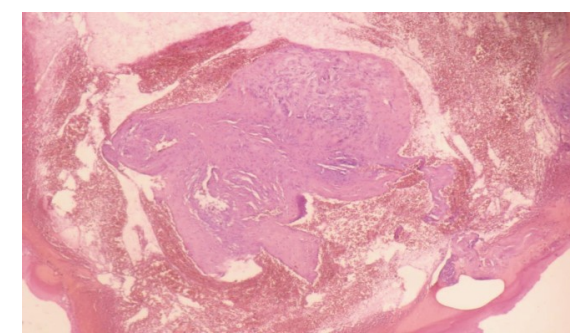

Gambar 2. Massa multinoduler kecil hingga besar. (HE, x40).

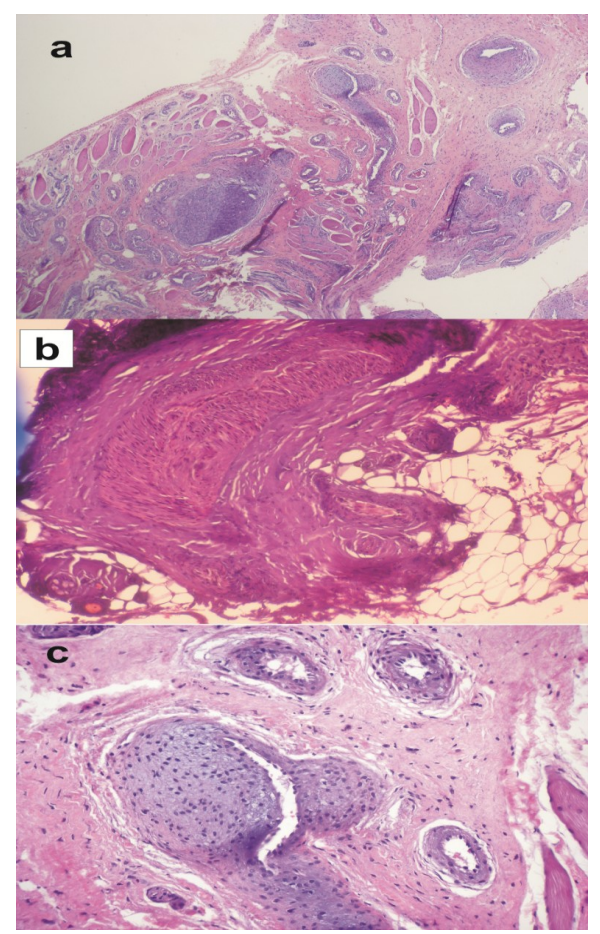

Gambar 3. (a) Pembuluh darah dan jaringan saraf dengan ukuran yang bervariasi. (x40). (b) Penebalan jaringan saraf terdapat di antara jaringan ikat. ( x100). (c) Pembuluh darah proliferatif. (x200).

\section{PEMBAHASAN}

Mayoritas penyakit yang ditemukan di literatur oral maksilofasial patologi melibatkan proliferasi seluler. Pembesaran massa seringkali disamaratakan sebagai tumor, tanpa membedakan patologi spesifik dan sifat dasarnya. Oleh karena itu pembesaran massa sederhana seperti traumatik fibroma atau piogenik granuloma dianggap sebagai tumor layaknya ossifying fibroma atau pleomorfik adenoma. Pembagian proliferasi seluler menjadi hiperplasia, hamartoma, choristoma, teratoma, neoplasma jinak, dan neoplasma ganas diperlukan untuk mengetahui terapi pilihan berdasarkan sifat masing-masing kelompok tersebut. ${ }^{2}$ Oleh karena itu untuk memastikan diagnosis diperlukan pemeriksaan secara histopatologis.

Hamartoma merupakan nodul jinak menyerupai tumor yang terdiri dari pertumbuhan berlebih sel-sel dan jaringan matur yang normal terdapat di bagian yang bersangkutan. ${ }^{4}$ Pertumbuhannya memiliki koordinasi dengan jaringan individu, tidak tumbuh otonom seperti neoplasma, selalu jinak, biasanya terdiri atas dua atau lebih tipe sel matur, ${ }^{5}$ namun sering didominasi oleh salah satu elemen. ${ }^{4}$ Hamartoma dapat terjadi di organ apapun dan tanpa batasan usia. Dilaporkan hamartoma juga terjadi pada anakanak dan balita pada testis, berupa hamartoma vaskular. ${ }^{6}$ Pada daerah rongga mulut, hamartoma relatif umum terjadi, khususnya dalam bentuk vascular malformation. Penelitian mengenai vascular malformation yang dilakukan pada salah satu universitas di Brazil selama 10 tahun (1992-2002) terhadap 2.419 kasus, didapati prevalensinya sebesar $1,3 \%{ }^{7} \quad$ Sedangkan hamartoma intraoral yang terdiri dari jenis jaringan lainnya sangat jarang ditemukan. Bila ditemui, kebanyakan kasus yang dilaporkan terdapat pada atau sekitar midline posterior lidah, palatum durum, dan gingiva. ${ }^{8}$ Kelainan rongga mulut lainnya yang dapat dikelompokkan ke dalam hamartoma ialah odontoma dan fibrous 
dysplasia. $^{9}$

Hamartoma memiliki gambaran proliferasi dismorfik jaringan yang berasal dari area tertentu. Hamartoma tidak memiliki kemampuan untuk melanjutkan pertumbuhan, namun hanya berjalan seiring dengan pertumbuhan badan. Perbedaan antara hamartoma dan neoplasma jinak seringkali berubah-ubah. Hemangioma, pigmented nevus, odontoma, ameloblastik fibroodontoma sering dikelompokkan dalam hamartoma. $^{2}$ Hamartoma umumnya kongenital $^{10}$ dan sifat yang menonjol ialah pertumbuhannya berhenti pada saat tertentu ${ }^{2}$ (memiliki periode pertumbuhannya sendiri) ${ }^{10}$ serta tidak menginfiltrasi jaringan di sekitarnya. Proliferasi pada hamartoma tidak berhubungan dengan stimulus tertentu. Oleh karena itu, jika terjadi pada tulang, hamartoma diterapi dengan enukleasi dan jika terjadi pada jaringan lunak, maka dengan eksisi perikapsular lokal. ${ }^{2}$ Saat hamartoma telah mencapai dimensi dan ukuran matur, pertumbuhannya tidak akan meluas dan jarang disertai pertambahan ukuran, kecuali jika terdapat trauma, thrombosis, atau infeksi yang menyebabkan edema, infiltrasi peradangan, serta bertambahnya pembuluh darah baru. ${ }^{10}$

Kasus serupa dengan hamartoma pada kasus ini pernah dilaporkan oleh R. K. Jain di India. Disebutkan terdapat pasien laki-laki berusia 18 tahun yang mengunjungi Poli THT dengan keluhan meningkatnya pembengkakan di pipi yang bertahap sejak lahir (Gambar 4). Pembengkakan tidak mengalami pembesaran dalam 2-3 tahun terakhir. Pada pemeriksaan ditemukan pembengkakan berukuran $8 \times 8 \mathrm{~cm}$ meluas dari bibir hingga angulus mandibula, berbatas jelas tanpa disertai keluhan nyeri. Pada pemeriksaan dari sisi bukal didapati nodul-nodul keras. Pemeriksaan histopatologis menetapkan diagnosis neurofibroma hamartoma. ${ }^{3}$ Pada kedua kasus terdapat kemiripan lesi dalam lokasi, ukuran, riwayat kongenital, memiliki periode pertumbuhannya sendiri, dan tanpa adanya keluhan nyeri.

Pada awal kasus berdasarkan data-data klinis yang didapatkan, telah dilakukan pendekatan diagnosis tumor, yakni kecurigaan klinis yang dilanjutkan dengan diagnosis laboratorium. ${ }^{5}$ Riwayat penyakit merupakan langkah pertama dalam penegakan diagnosis. Hal ini meliputi riwayat keluarga yang penting untuk predisposisi genetik; riwayat merokok, riwayat paparan terhadap sinar matahari, riwayat terpapar bahan kimia, jenis makanan, dan lain-lain. Riwayat penyakit yang lengkap mencakup semua kemungkinan faktor penyebab maupun kemungkinan pengaruh neoplasma kepada pasien. Pemeriksaan fisik digunakan untuk menemukan keluhan dan tanda-tanda setempat serta massa tumor yang dapat di biopsi untuk pemeriksaan patologi. ${ }^{5}$ Dalam pendekatan diagnostik tumor terdapat beberapa cara diagnostik laboratorium, yakni pemeriksaan histopatologi blok parafin, pemeriksaan potong beku, pemeriksaan biopsi aspirasi jarum halus (FNAB = fine needle aspiration biopsy), pemeriksaan imunohistokimia, dan pengujian biokimia. ${ }^{5}$
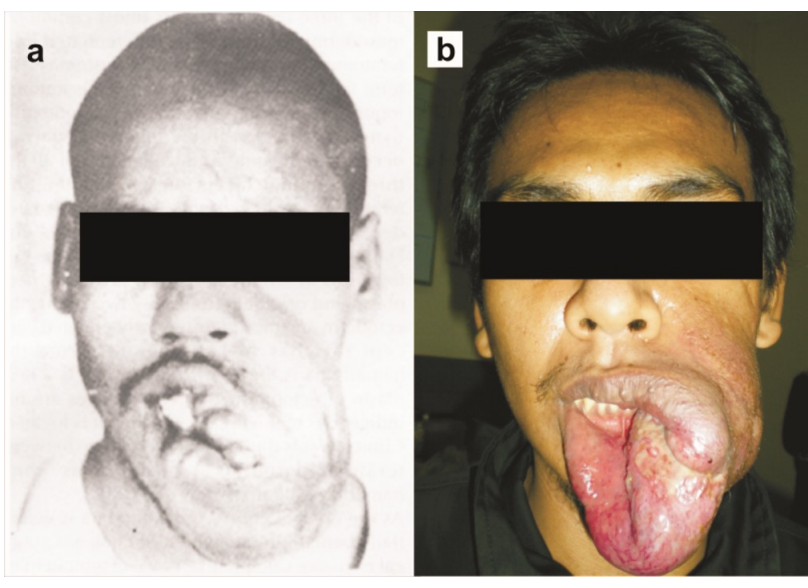

Gambar 4. (a) merupakan Neurofibroma Hamartoma yang dilaporkan RK Jain di India, sedangkan (b) merupakan Hamartoma kasus ini.

Pada kasus ini, diagnostik laboratorium yang dilakukan ialah pemeriksaan histopatologi blok parafin dengan sediaan yang berasal dari biopsi dan pemeriksaan potong beku. Pada pemeriksaan histopatologi sebelum 
dilaksanakannya percobaan operasi, didapati kasus merupakan neuroma bukal. Sedangkan pada hasil pemeriksaan yang dilakukan setelahnya, didapati kasus berubah menjadi hamartoma. Sebagai catatan, pada beberapa keadaan, diagnosis morfologik suatu tumor sangat sukar karena suatu sebab. Maka sangat penting agar klinisi dapat melakukan biopsi yang representatif. ${ }^{1}$ Pengambilan jaringan yang adekuat dan tepat pada biopsi merupakan hal yang esensial bagi pemeriksaan, diagnosis, dan juga terapi. Ketepatan yang dimaksud ialah jaringan tersebut representasi dari lesi secara keseluruhan. Hal ini bergantung pada tiga faktor, yakni pemilihan tempat biopsi, cara biopsi, dan juga besaran spesimen yang dikirim ke laboratorium. Besaran ini penting, dimana jika terlalu kecil, maka terdapat kemungkinan terjadi kehilangan atau distorsi jaringan saat pemprosesan. Selain hal tersebut, deskripsi klinis yang akurat dan relevan akan membantu ahli patologi dalam mengambil kesimpulan. ${ }^{11}$ Untuk lesi kecil, dapat dipilih biopsi eksisi, sedangkan untuk lesi yang besar, mungkin terdapat perbedaan gambaran histologi antara sisi yang satu dengan yang lainnya. Sebagai contoh pada karsinoma sel skuamosa yang besar, mungkin terdapat area yang menunjukkan gambaran invasif, sedangkan area lainnya hanya menunjukkan displasia epitel. Sisi yang dipilih untuk biopsi, khususnya untuk lesi yang besar, harus dapat merepresentasikan keadaan patologis secara keseluruhan. Pada situasi tersebut, akan lebih tepat jika dilakukan biopsi kecil multipel. Hal ini didukung oleh penelitian oleh Lee et al., yang menemukan bahwa rerata kecocokan antara biopsi tunggal dibandingan dengan diagnosis histologi setelah lesi direseksi hanya 56\%. Sedangkan Logan dan Goss menemukan bahwa persentase under diagnosed dapat diturunkan dari $29 \%$ menjadi $11,9 \%$, jika dilakukan biopsi multipel. ${ }^{11}$

Disamping pengambilan jaringan yang representatif, masih terdapat faktor-faktor lain yang dapat mempengaruhi gambaran histologi dari jaringan yang diambil. Kehati-hatian dalam teknik pembedahan sangat penting. Sebagai contoh, penggunaan pinset jaringan yang tidak hati-hati dapat merusak jaringan sehingga mengganggu gambaran mikroskopis. Jika terdapat biopsi atau pembedahan yang telah dilakukan sebelumnya pada area biopsi, maka hal ini akan menampakkan gambaran penyembuhan atau inflamasi yang menutupi gambaran sebenarnya. Faktor lainnya seperti laser, electrosurgery, serta fiksasi jaringan setelah pengambilan sampel juga dapat menyebabkan artefak atau distorsi jaringan. ${ }^{11}$ Pada kasus ini, perbedaan hasil kesimpulan pemeriksaan patologi di atas mungkin juga disebabkan karena tidak disertainya informasi klinis yang memadai sebagai penunjang dalam pembuatan kesimpulan histopatologi. Sehingga bila didapati ketidaksesuaian antara gambaran histopatologi yang didapati dengan gambaran klinis, maka dokter patologi anatomi dapat menyarankan dilakukannya pemeriksaan tambahan yang diperlukan, seperti biopsi ulang, pengambilan sampel dengan cara yang lain, atau dilakukan pemeriksaan penunjang lainnya. Informasi klinis harus dipertimbangkan dalam penilaian jaringan biopsi. Terdapat dua tingkat yang berbeda dalam penilaian jaringan biopsi, yakni penilaian perubahan histopatologik jaringan yang terjadi; dan analisis perubahanperubahan ini berdasarkan keadaan klinik dan morfologiknya. Sebagai contoh, gambaran histologi lemak subkutis dari daerah abdomen tidak akan berbeda dengan gambaran histologi lemak yang berasal dari kerokan endometrium. Pada keadaan pertama jaringan lemak merupakan jaringan lemak normal, sedangkan pada keadaan kedua merupakan lemak yang berasal dari omentum akibat perforasi usus. ${ }^{1}$ Namun demikian, klinisi dapat menginisiasi dilakukannya pemeriksaan lanjutan bila dicurigai adanya ketidaksesuian antara hasil kesimpulan pemeriksaan histopatologi dengan gambaran klinis. Hal ini dapat dilakukan baik dengan memohon dilakukannya slide review yang disertai 
informasi klinis yang lebih lengkap, maupun langsung melakukan pengambilan sampel ulang.

\section{SIMPULAN}

Hamartoma merupakan salah satu jenis lesi proliferasi seluler yang dapat terjadi di daerah rongga mulut, misalnya di regio bukal. Penegakan diagnosis kasus hamartoma memerlukan pemeriksaan yang menyeluruh meliputi pemeriksaan klinis dan penunjang yakni biopsi, CT scan, dan radiograf. Khusus untuk biopsy, diperlukan pengambilan jaringan yang adekuat dan representatif, dalam hal ini biopsi multipel akan lebih mereprentasikan keadaan patologis pada lesi besar. Penyertaan informasi klinis yang memadai diperlukan untuk mengurangi keterbatasan pemeriksaan histopatologi.

\section{DAFTAR PUSTAKA}

1. Tjarta A. Neoplasma. Patologi. Jakarta: Bagian Patologi Anatomik Fakultas Kedokteran Universitas Indonesia; 1973. Indonesian.

2. Marx RE, Stern D. Hyperplasias, hamartomas, and neoplasms: their biology and its impact on treatment decisions. In: Bywaters LC, editor. Oral and Maxillofacial Pathology : A Rationale for Diagnosis and Treatment. Illinois: Quintessence Publishing Co, Inc; 2003.

3. Jain RK. Hamartoma of the Head and Neck. Indian J Otolaryngol Head Neck Surg. 1999;51 (4):76-8.

4. Rima MH. Kamus Kedokteran Dorland ed 26. Jakarta: EGC; 1994.

5. Tjarta A. Neoplasia. Buku Ajar Patologi I (Umum) ed 1. Jakarta: Sagung Seto; 2002. Indonesian.

6. Bodas A, Rivilla F, Casillas JG. Vascular hamartoma: another cause of testicular torsion in a newborn. Acta Paediatr. 1998;87(8):910.

7. Corrêa PH, Nunes LC, Johann AC, Aguiar MC, Gomez RS, Mesquita RA. Prevalence of oral hemagioma, vascular malformation and varix in a Brazilian population. Braz Oral Res. 2007;21 (1):40-5.

8. Paede la Rosa-García E, Mosqueda-Taylor A.Rosa -Gracia ED, Mosqueda-Taylor A. Leimyomatous hamartoma of the anterior tongue: report of a case and review of the literature. Int $\mathrm{J}$ Pediatr Dent. 1999;9(2):129-32.
9. Mehra P. Benign cysts and tumors of the jaw bones. In: Fred JS, de Souza C, Kenyon GS, Lian TS, Draf W. Rhinology and facial plastic Surgery. 2009. p. 415-7.

10. Eversole LR. Benign Tumors of the Oral Cavity. In: Greenberg MS, Glick M, editors. Burket's Oral Medicine Diagnosis \& Treatment $10^{\text {th }}$ ed. Ontario: BC Decker Inc; 2003.

11. Logan R, Goss A. Biopsy of the oral mucosa and use of histopathology services. Aus Dent J. 2010; 55(1 Suppl):8-13. 